\title{
Environmental impact assessment of organic waste conversion technology for additives to liquid fuels
}

ABSTRACT: In this study, the environmental impacts of the organic fraction of municipal solid waste (OFMSW) treatment and its conversion in anaerobic digestion to glycerol tertiary butyl ether (GTBE) were assessed. The production process is a part of the innovative project of a municipal waste treatment plant. The BioRen project is funded by the EU's research and innovation program H2020. A consortium has been set up to implement the project and to undertake specific activities to achieve the expected results. The project develops the production of GTBE which is a promising fuel additive for both diesel and gasoline. It improves engine performance and reduces harmful exhaust emissions. At the same time, the project focuses on using non-recyclable residual organic waste to produce this ether additive.

The aim of this paper is the evaluation through Life Cycle Assessment of the environmental impact GTBE production in comparison with a production of other fuels. To quantify the environmental impacts of GTBE production, the ILCD 2011 Midpoint+ v.1.10 method was considered. The study models the production of GTBE, including the sorting and separation of municipal solid waste (MSW), pre-treatment of organic content, anaerobic fermentation, distillation, catalytic dehydration of isobutanol to isobutene, etherification of GTBE with isobutene and hydrothermal carbonization (HTC).

$\triangle$ Corresponding Author: Magdalena Muradin; e-mail: muradin@meeri.pl

1 Mineral and Energy Economy Research Institute of the Polish Academy of Sciences, Kraków, Poland; ORCID iD: 0000-0003-1209-0018; e-mail: muradin@meeri.pl

2020. The Author(s). This is an open-access article distributed under the terms of the Creative Commons Attribution-ShareAlike International License (CC BY-SA 4.0, http://creativecommons.org/licenses/by-sa/4.0/), which permits use, distribution, and reproduction in any medium, provided that the Article is properly cited. 
The results indicate that unit processes: sorting and hydrothermal carbonization mostly affect the environment. Moreover, GTBE production resulted in higher environmental impact than the production of conventional fuels.

KEYwords: life cycle assessment (LCA), organic municipal waste, biofuels, additives to liquid fuels, glycerol tertiary butyl ether (GTBE)

\section{Introduction}

The implementation of the sustainable development principles is not about maintaining a status quo environment, but about resources management and approach to the economy in such a way as to reduce global exploitation of the Earth and the mitigation of human negative activities. The European Parliament resolution assigned in 2019 on the climate and environment emergency helps to reduce pollution levels and climate change mitigation (EP 2019). However, it is still insufficient to maintain the biodiversity and to prevent the further intensification of a crisis and reduce the global temperature growth. There is an urgent need to implement and develop many new technologies especially in energy, transport and the waste management sector.

The total amount of greenhouse gas emissions in EU-28 including Iceland reached 4,333 million tons of $\mathrm{CO}_{2}$ equivalent in 2017. Comparing with the year 1990 it decreased by $23.5 \%$ however, between 2016 and 2017 the GHG emissions grew by $0.5 \%$ (EEA 2019). In particular, this is a result of the growing share in the use of renewables, structural changes in the economy and the economic recession as well as the development of energy efficient technologies. One of the exceptions is road transport, including international transport, where the GHG emissions rose by 170 million tons of $\mathrm{CO}_{2}$ equivalent between 1990 and 2017 (EEA 2019).

The production of biofuels, primarily biodiesel and bioethanol used as transport fuels, provides an alternative to the production of energy from conventional fuels. The aim of using biofuels is to reduce greenhouse gas emissions into the atmosphere and prevent climate change. Based on Renewable Energy Directive (RED), which is part of the Climate Change Package (CCP) the mandatory goals for 2020 was to reach a $10 \%$ percent share of energy from renewable energy blending target used for transport sector (EU 2009). It is still unknown whether the goal has been achieved, however in 2017 it was 7.6\% (Eurostat 2019). The RED II was published for the years 2021-2030, which sets the target of 14\% for transport sector from the renewables, where among that, non-food based biofuels (not derived from fats and oils) should be 3.5 percent by 2030 (EU 2018).

Except for resource depletion and climate change, the greatest potential of environmental impacts are associated to waste management. All these three elements are closely related, and changes in the traditional technologies can bring real benefits. The elimination of landfills in favor of an incinerator for energy recovery is no longer a solution. Firstly, the aim is to reduce the amount of waste generated. It can only afterwards be recycled. According to Eurostat data, in 2016 in the 
EU, $45.7 \%$ of waste was landfilled and $37.8 \%$ was recycled. The BiorRen project funded by the H2020 research and innovation program is a biomass waste treatment technology chain which is part of a waste processing system connecting mechanical, thermal and biological processes. The objective of BioRen is to develop competitive drop-in biofuels, mainly a glycerol tertiary butyl ether (GTBE) for a road transport, from the organic fraction of municipal solid waste (OFMSW) The organic fraction consists mainly of residual paper and cardboard residues which cannot be recycled. Other biofuels produced as intermediates throughout the GTBE production chain are bio-ethanol and bio-isobutanol. In the case of low GTBE cost-effectiveness, the production of these $2^{\text {nd }}$ generation biofuels is planned as main products excluding GTBE synthesis in the production chain (Muradin and Cholewa 2019).

Among other derivatives as methanol, ethanol or tert-butyl methyl ether (MTBE), glycerol tertiary butyl ether (GTBE) is a promising fuel additive to both diesel and gasoline that improves engine performance and cuts harmful exhaust emissions. It can be synthesized from two types of intermediaries: bio-ethanol and bio-isobutanol. The GTBE can be blended in higher amounts than ethanol, without having to change the engine performance. Incorporating the GTBE in standard diesel fuel decreases the emissions of: particulate matter, hydrocarbons, carbon monoxide, and unregulated aldehydes (Kijeński et al. 2007; Cherubini et al. 2009; Beatrice et al. 2014; Huang and Kim 2015; Daylan and Ciliz 2016). On the other hand the additive of GTBE to diesel fuel with a low cetane number leads to the increase in $\mathrm{NO}_{2}$ emissions (Bozkurt et al. 2019).

The literature analysis has been taken not only to overview the similar processes and their environmental burdens but also to enable the life cycle inventory analysis of the BioRen processes and find the proper comparable data. Therefore the aim of this paper is the evaluation through Life Cycle Assessment of the environmental impact of GTBE production and indirectly the impact on human health, quality of the ecosystem and on resources in comparison with a production of other liquid fuels taken from Ecoinvent database. At this stage of the study, only the production process was taken into account, while a fuel combustion in vehicles was excluded from system boundaries (cradle to gate analysis). A lot of studies can be found about life cycle assessment (LCA) and environmental impacts for the biofuels production of lignocellulosic biomass materials (Stichnothe and Azapagic 2009; Borrion et al. 2012; Schmitt et al. 2012; Singh et al. 2013; Moncada et al. 2017) However there is a little research on LCA for processing organic fraction of municipal waste into biofuels.

\section{Materials and methods}

ISO 14040 and 14044 standard LCA methodology is used for this study, which includes four steps: goal and scope definition, life cycle inventory analysis, life cycle impact assessment, interpretation and results (ISO 14040:2006, ISO 14044:2006). In this work the ILCD 2011 Midpoint+ v.1.10 method was considered. The ILCD is developed by the Institute for Environment and 
Sustainability in the European Commission Joint Research Centre (JRC), in cooperation with the Environment DG which is widely used in Europe. Due to the midpoint approach it is very detailed in the 16 impact assessment categories (EC 2011). The study models the production of GTBE including the carbonization process of biomass sludge after the anaerobic waste fermentation. The recovery of non-biogenic content of MSW after the separation and sorting processes was excluded in this study (Meng et al. 2019). The inventory data was taken from Ecoinvent database, literature (Cherubini et al. 2009; Asdrubali et al. 2015; Toufiq Reza et al. 2016) and primary source. The life cycle analysis was carried out with SimaPro v.9.0.0. software (Pre Consultants, Amersfoort, The Netherlands) using Ecoinvent 3.3 inventory databases.

\subsection{Goal and scope definition}

The goal of this LCA study was to assess the potential environmental impacts of producing a glycerol tertiary butyl ether (GTBE) as an additive to diesel fuel. The allocation cut off by classification was used in this study and the primary production of main input: OFMSW and glycerol was allocated to the primary producer/user of the material. This means that environmental burdens associated with processes responsible for generating MSW and glycerol were excluded from the study. The production processes were also excluded for phosphoric acid and enzymes because the environmental burdens belong to the primary production processes (Daylan and Ciliz 2016). Assessing the impact of all input materials only their transportation to the facility was considered. It was also considered that the main product was GTBE with $100 \%$ allocation. The functional unit FU was used as a reference to quantify all inputs and outputs and is defined as "100 kg of liquid GTBE produced in the BioRen installation plant". The system boundary includes 1) the sorting of municipal solid waste (MSW), 2) pre-treatment of organic content, 3) anaerobic, 4) fermentation, 5) distillation, 6) catalytic dehydration of isobutanol to isobutene, 7) etherification of GTBE with isobutene and 8) hydrothermal carbonisation (HTC). A schematic processes with system boundaries definition is shown in Figure 1.

\subsection{Live cycle inventory}

Due to the fact that mainly a detailed data for unit processes of BioRen installation is still not available, the inventory data for LCA analysis was taken from literature. Data about sorting process and MSW composition was based on (Cherubini et al. 2009). Data about the chemical conversion of isobutanol was taken from (Tao et al. 2014; Asdrubali et al. 2015). Data about the fermentation process and chemical conversion of municipal solid waste into butanol and ethanol was based on (Meng et al. 2019). All the information about hydrothermal carbonisation process was provided by Ingelia and based on Ingelia pilot plant. Asdrubali et al. (2015) presented the 


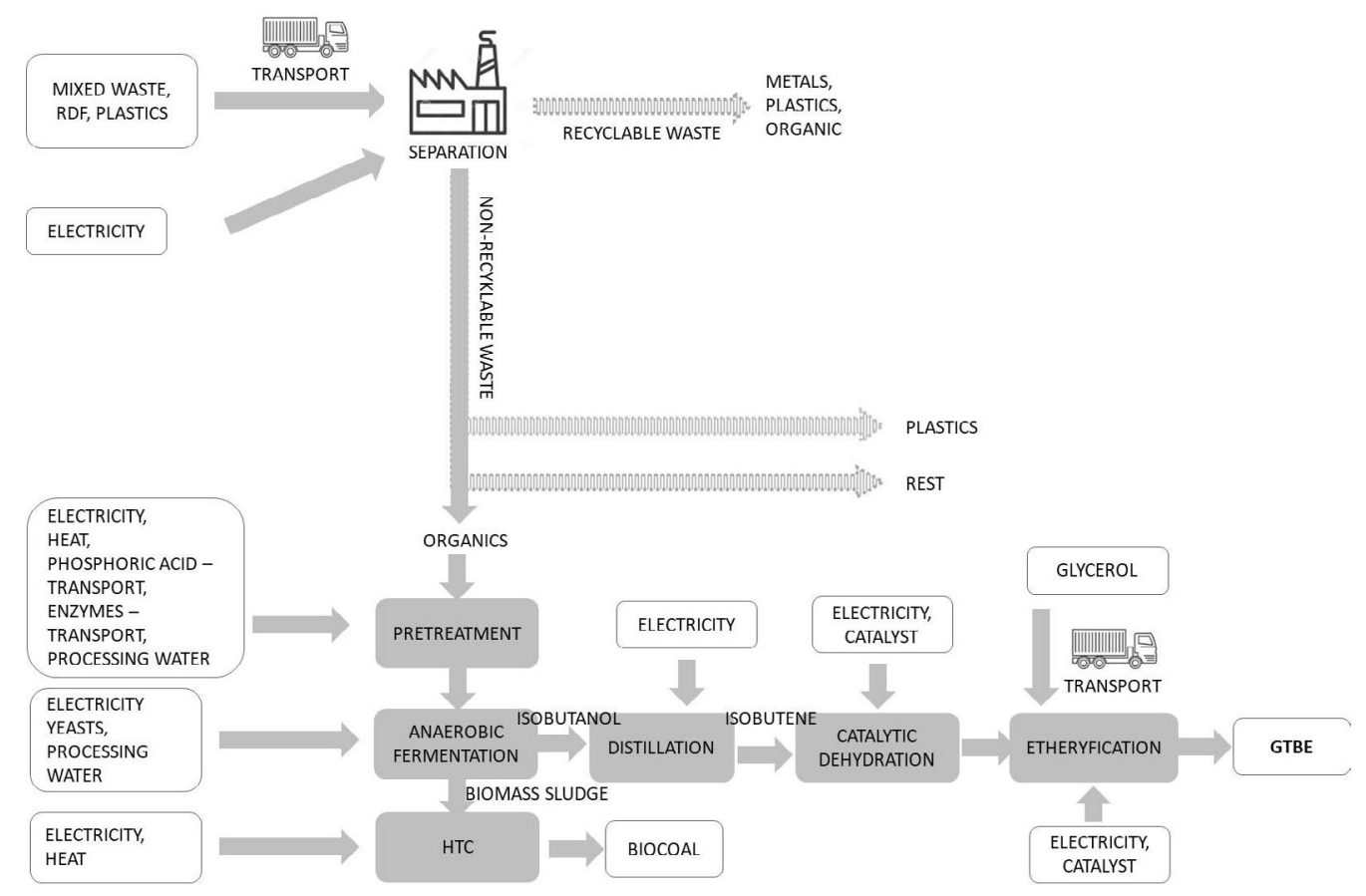

Fig. 1. Schematic processes of BioRen project with system boundaries definition Source: own studies based on BioRen project

Rys. 1. Schemat procesów dla projektu BioRen wraz z określeniem granic systemu

results about life cycle assessment analysis for the etherification process of glycerol and isobutanol to obtain a glycol-ethers mixture which enabled us to gather data about GTBE production. The data about the process efficiency was taken from the general information about the BioRen project. All the materials and energy flows are presented in Table 1.

\section{Results}

The ILCD method applied in this study aggregates environmental impacts in single scores expressed in Points [Pt]. The highest score means the worst environmental impact. The whole GTBE production process was subdivided for unit processes. The results of total environmental impact for each life cycle stage are as follow: sorting $(328.86 \mathrm{mPt})$, pre-treatment $(10.35 \mathrm{mPt})$, fermentation $(103.85 \mathrm{mPt})$, etherification $(6.58 \mathrm{mPt})$, distillation $(25.42 \mathrm{mPt})$, catalytic dehydration $(0.45 \mathrm{mPt})$ and hydrothermal carbonization $(209,06 \mathrm{mPt})$. The highest environmental impact concerns sorting and carbonization processes (Fig. 2). Municipal waste separation is the factor 
TABLE 1. Inputs and outputs for GTBEs unit production processes

TABELA 1. Wejścia i wyjścia dla procesów produkcji GTBE

\begin{tabular}{|c|c|c|c|c|c|c|}
\hline Unit process & Input & Amount & Unit & Output & Amount & Unit \\
\hline \multirow{2}{*}{$\begin{array}{c}\text { Sorting } \\
\text { (Cherubini et al. 2009) }\end{array}$} & MSW transport & 1030.26 & tkm & & & \\
\hline & electricity & 0.19 & MWh & & & \\
\hline \multirow{5}{*}{$\begin{array}{c}\text { Stabilization } \\
\& \text { pre-treatment } \\
\text { (Daylan and Ciliz } \\
\text { 2016) }\end{array}$} & $\begin{array}{l}\text { transport } \\
\text { of phosphoric acid }\end{array}$ & 1.14 & $\mathrm{tkm}$ & & & \\
\hline & steam & 5.00 & GJ & & & \\
\hline & processing water & 124.80 & $\mathrm{t}$ & & & \\
\hline & transport of enzymes & 0.05 & tkm & & & \\
\hline & electricity & 2.56 & $\mathrm{kWh}$ & & & \\
\hline \multirow{3}{*}{$\begin{array}{c}\text { Fermentation } \\
\text { (Meng et al. 2019) }\end{array}$} & yeasts & 63.49 & $\mathrm{~kg}$ & ethanol* & 34.89 & $\mathrm{~kg}$ \\
\hline & processing water & 104.19 & $\mathrm{t}$ & isobutanol* & 238.74 & $\mathrm{~kg}$ \\
\hline & electricity & 4.42 & $\mathrm{kWh}$ & biomass sludge* & 14.30 & $\mathrm{t}$ \\
\hline \multirow{2}{*}{$\begin{array}{c}\text { Distillation } \\
\text { (Meng et al. 2019) }\end{array}$} & electricity & 25.12 & $\mathrm{kWh}$ & & & \\
\hline & heat & 3976.95 & MJ & & & \\
\hline \multirow{10}{*}{$\begin{array}{l}\text { Carbonization (data } \\
\text { taken from project } \\
\text { partner) }\end{array}$} & electricity & 534.58 & $\mathrm{kWh}$ & oil & 7.64 & $\mathrm{~kg}$ \\
\hline & thermal energy & 3894.76 & $\mathrm{kWh}$ & water & 4948.64 & $\mathrm{~kg}$ \\
\hline & biomass sludge* & 14.30 & $\mathrm{t}$ & separated inerts & 1023.33 & $\mathrm{~kg}$ \\
\hline & & & & water evaporation & 4612.62 & $\mathrm{~kg}$ \\
\hline & & & & emissions: & & \\
\hline & & & & $\mathrm{NO}_{\mathrm{x}}$ & 0 & $\mathrm{~kg}$ \\
\hline & & & & $\mathrm{CO}_{2}$ & 106.92 & $\mathrm{~kg}$ \\
\hline & & & & $\mathrm{CO}$ & 1.53 & $\mathrm{~kg}$ \\
\hline & & & & $\mathrm{SO}_{2}$ & 0 & $\mathrm{~kg}$ \\
\hline & & & & $\mathrm{PM}$ & 0.53 & $\mathrm{~kg}$ \\
\hline \multirow{2}{*}{$\begin{array}{l}\text { Catalytic dehydration } \\
\quad \text { (Tao et al. 2014; } \\
\text { Asdrubali et al. 2015) }\end{array}$} & isobutanol* & 283.74 & $\mathrm{~kg}$ & isobutene* & 154.60 & $\mathrm{~kg}$ \\
\hline & electricity & 1.40 & $\mathrm{kWh}$ & water & 49.69 & $\mathrm{~kg}$ \\
\hline \multirow{6}{*}{$\begin{array}{c}\text { Etherification } \\
\text { (Asdrubali et al. 2015) }\end{array}$} & glycerol & 63.50 & $\mathrm{~kg}$ & GTBE & 100.00 & $\mathrm{~kg}$ \\
\hline & isobutene* & 154.60 & $\mathrm{~kg}$ & & & \\
\hline & transport of glycerol & 0.05 & $\mathrm{tkm}$ & & & \\
\hline & deionized water & 10.90 & $\mathrm{~kg}$ & & & \\
\hline & steam/pressure & 102.00 & $\mathrm{~kg}$ & & & \\
\hline & electricity & 1.40 & $\mathrm{kWh}$ & & & \\
\hline
\end{tabular}

* Environmental burdens of intermediate products were not included because of their transformation only within the same technosphere.

Source: own studies based on the BioRen project. 
most affecting the environment in the sorting process. To facilitate the analysis and due to the main scope of the study all burdens concerning the separation were allocated to GTBE production, however the impact of municipal waste separation could be also allocated to the recycling of collected materials from waste. The extraction and separation of other types of inorganic materials from MSW (plastic, metals) were excluded from the study.

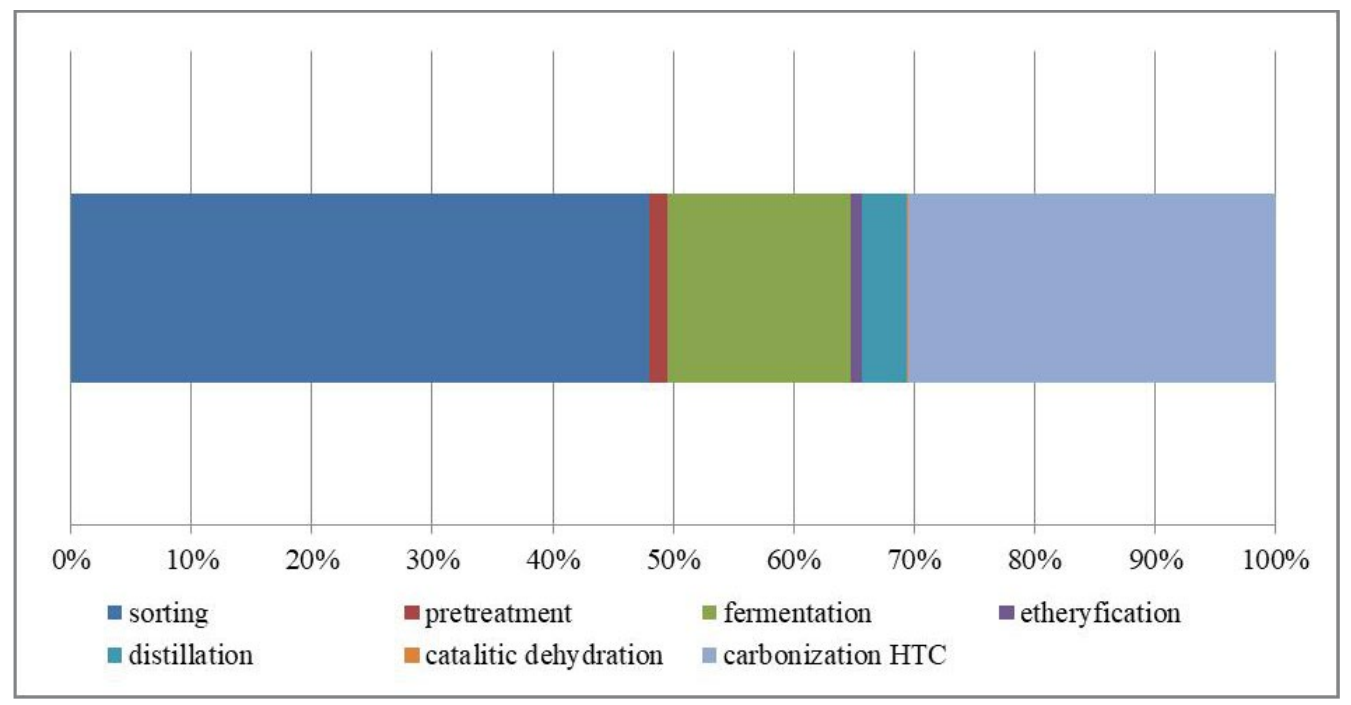

Fig. 2. The share of environmental impact for unit processes of GTBE production

Source: own studies

Rys. 2. Udział procesów jednostkowych w oddziaływaniu na środowisko procesu produkcji GTBE

The midpoint approach used in ILCD method means that results are divided for the particular impact categories:

$\checkmark$ climate change $(\mathrm{CCh})$,

$\checkmark$ ozone depletion (OD),

$\checkmark$ human toxicity - non-cancer effects (HT NCE),

$\checkmark$ human toxicity - cancer effects (HT CE),

$\checkmark$ particulate matter (PM),

$\checkmark$ ionizing radiation HH (IR),

$\checkmark$ photochemical ozone formation (POF),

$\checkmark$ acidification (AC),

$\checkmark$ terrestrial eutrophication (TE),

$\downarrow$ freshwater eutrophication (FE),

$\downarrow$ marine eutrophication (ME),

$\checkmark$ freshwater ecotoxicity (FTOX),

$\downarrow$ land use (LU), 
$\checkmark$ water resource depletion (WRD),

$\checkmark$ mineral, fossil \& renewable resource depletion (MFOS).

Figure 3 shows the percentage contribution of different impact categories for GTBE production. The GTBE production affects the environment mostly in three impact categories: human toxicity - cancer effects, ionizing radiation, human toxicity - non cancer effects. The reason can be electricity use from the grid and the transport of input materials. Only the carbonization process shows the positive effect in water resource depletion impact category, which can be connected with low dry biomass sludge processing.

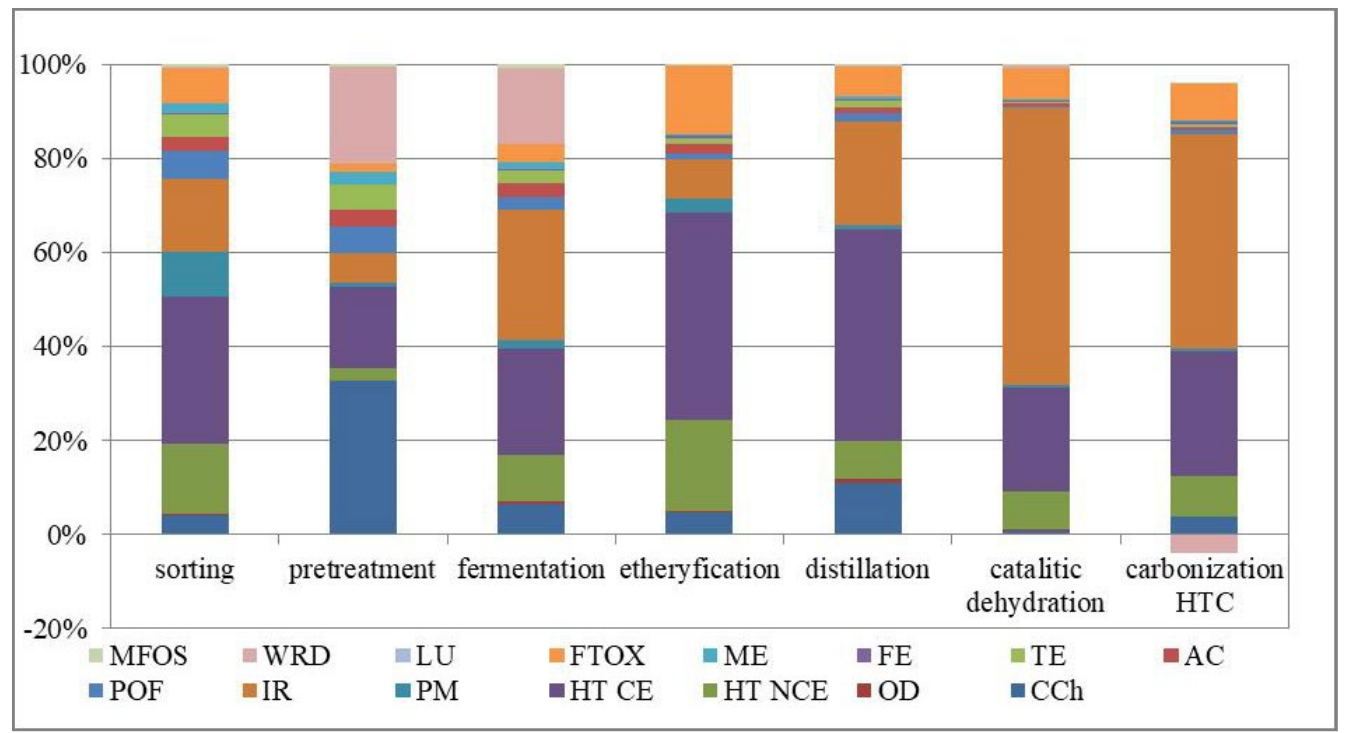

Fig. 3. Results for impact categories of GTBE production

Source: own studies

Rys. 3. Wyniki w kategoriach wpływu dla procesu produkcji GTBE

The results for GTBE production were compared with a production of other fuels:

1) diesel,

2) gasoline,

3) diesel with $15 \%$ of GTBE,

4) petrol 15\% ETBE from biomass.

The environmental impacts of those conventional fuels, as well as petrol with $15 \%$ ETBE additive, are substantially lower than the impact of a GTBE production in BioRen facility (Table 2).

The most damaging for the environment are three processes of GTBE production: sorting, fermentation and carbonization. For those processes, a more detailed analysis was conducted. Those processes were divided for subprocesses to assess which of them has the highest environmental impact (Fig. 4). 
TABLE 2. Environmental impact of production of selected fuels and GTBE

TABELA 2. Oddziaływanie na środowisko produkcji wybranych paliw oraz GTBE

\begin{tabular}{|l|r|c|}
\hline \multicolumn{1}{|c|}{ Fuel } & Total impact $[\mathrm{mPt}]$ & Source \\
\hline GTBE & 684.575 & own calculations \\
\hline Diesel with $15 \%$ of GTBE & 115.921 & Ecoinvent 3.3. database and own calculations \\
\hline Gasoline & 120.573 & Ecoinvent 3.3. database \\
\hline Diesel & 15.570 & Ecoinvent 3.3. database \\
\hline Petrol 15\% ETBE from biomass & 52.374 & Ecoinvent 3.3. database \\
\hline
\end{tabular}

Source: own studies.

Significant environmental impacts of sorting process mainly relate to the road transport of municipal waste to the facility site and the electricity consumption. In the case of the fermentation process, the critical point is the use of processing water, when in hydrothermal carbonization the most affecting the environment is electricity consumption from an external source. The total environmental impact of the GTBE production in BioRen plant was divided into main factors taken into account in the LCA analysis:

1) transport of materials,

2) electricity consumption,

3) heat/steam consumption,

4) water consumption,

5) others.

a)

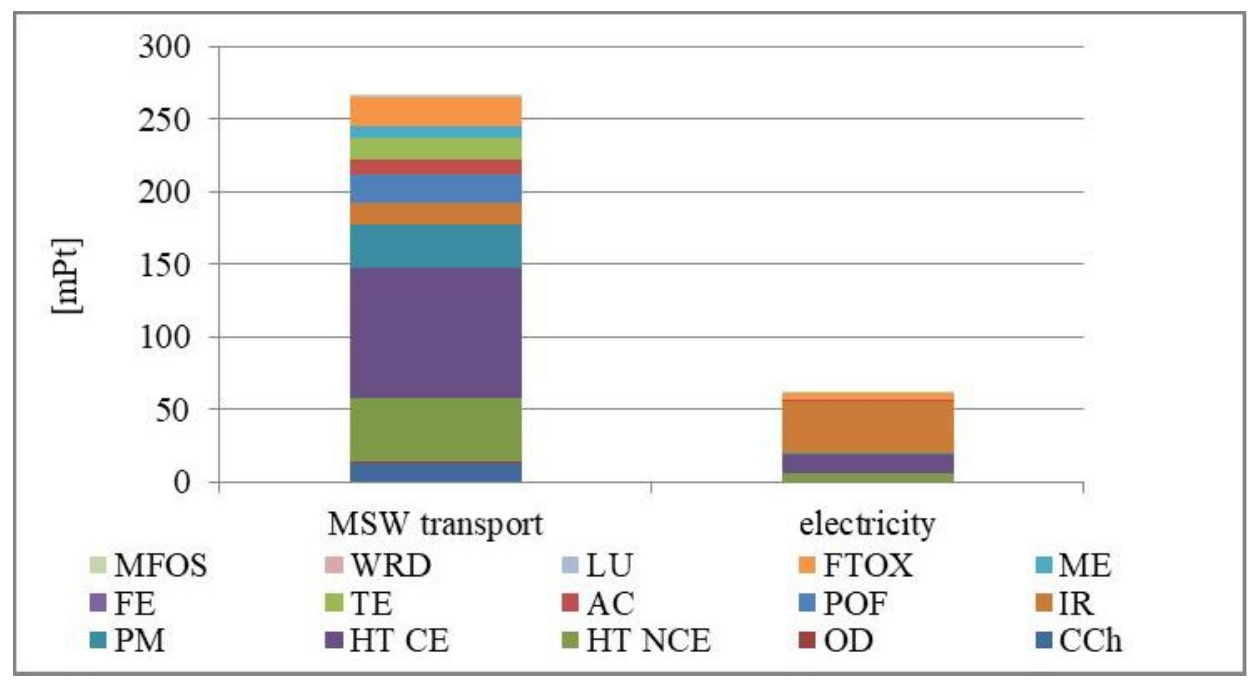

Fig. 4a. Results for impact categories for processes in GTBE production with a highest single score [mPt] a) sorting

Rys. 4a. Wyniki w kategoriach wpływu dla wybranych procesów produkcji z najwyższą wartością oddziaływania w punktach $[\mathrm{mPt}]$ a) sortowanie 
b)
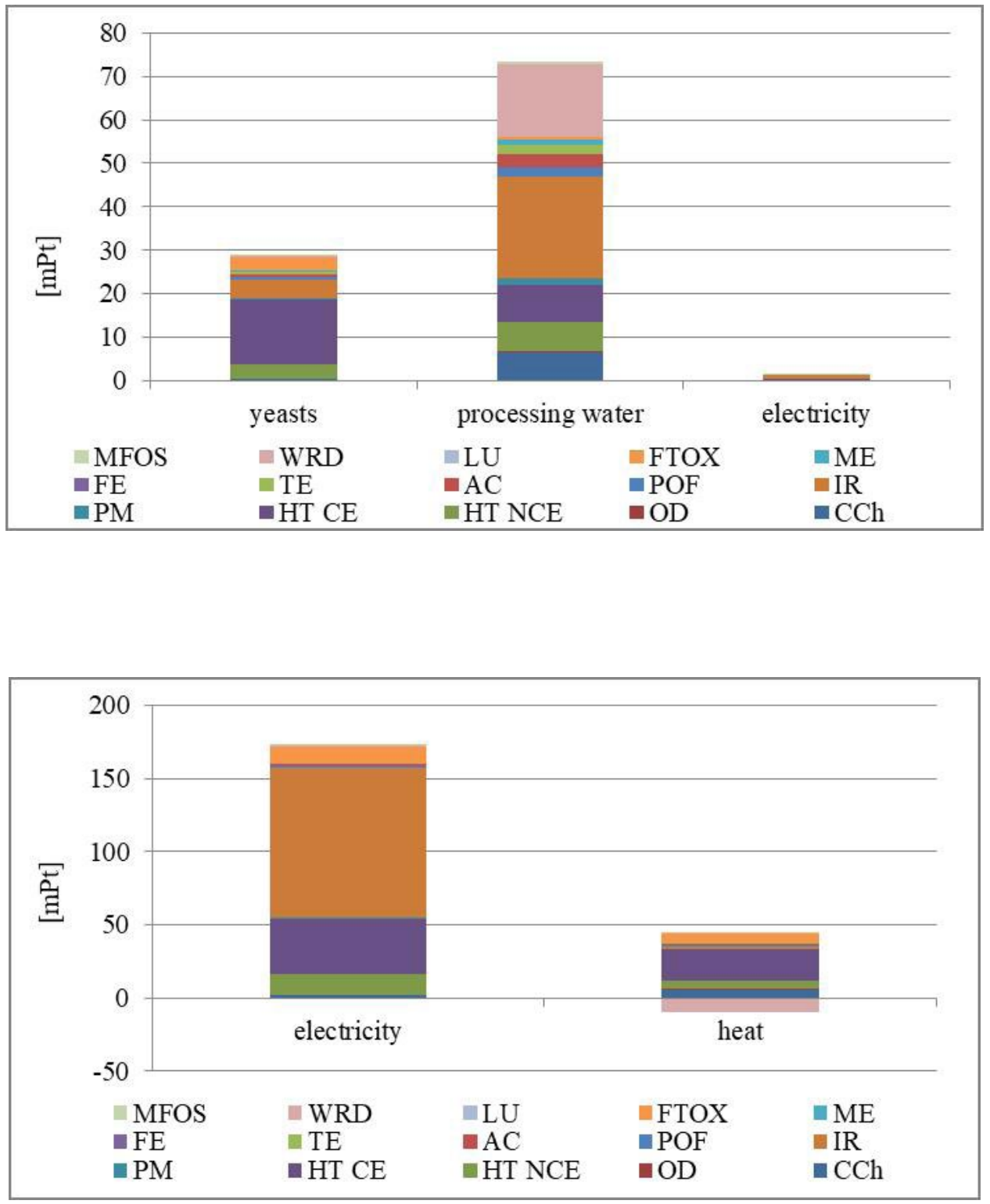

Fig. 4b,c. Results for impact categories for processes in GTBE production with a highest single score [mPt] b) fermentation, c) carbonization

\section{Source: own studies}

Rys. 4b,c. Wyniki w kategoriach wpływu dla wybranych procesów produkcji z najwyższą wartością oddziaływania w punktach $[\mathrm{mPt}]$ b) fermentacja, c) karbonizacja 
It turned out that the factor most affecting environment is the transport of materials needed during the production and the electricity consumption taken from the grid (Fig. 5). For transport and electricity consumption it is about $75 \%$ of the total environmental impact.

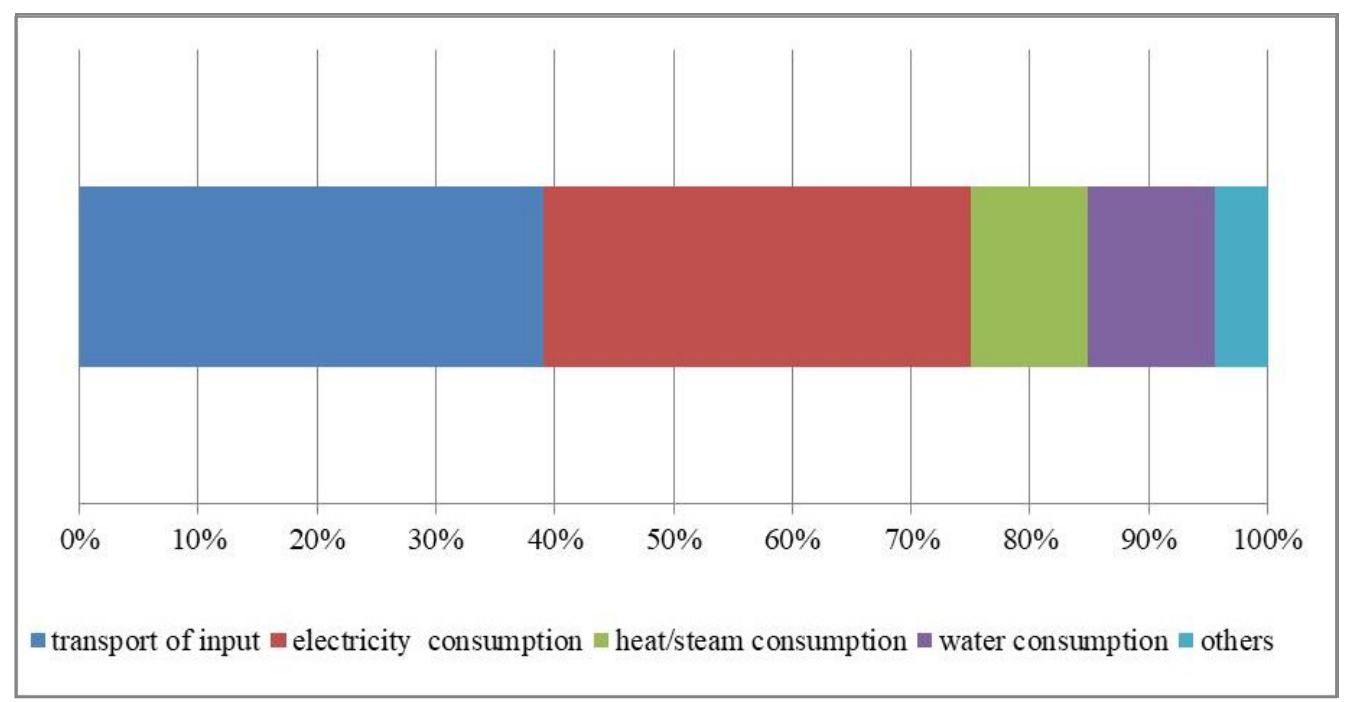

Fig. 5. The percentage distribution of environmental impact for main chosen factors

Source: own studies

Rys. 5. Udział procentowy oddziaływania na środowisko wybranych czynników

\section{Sensitivity analysis}

The transportation distance reduction will significantly diminish the environmental impact. Five different distances were analyzed starting from a distance of $10 \mathrm{~km}$ and increasing the distance to a maximum of $100 \mathrm{~km}$ (Fig. 6). A real state was also considered and defined as "business as usual" (BAU). The alternative excluding sorting was also measured. The length of the distance to which the municipal waste (the feedstock) is transported can mainly determine the environmental impact value of all the GTBE production technology (Fig. 6). It stems from the analysis that the MSW collection should be carried out in the vicinity of the facility to reduce the environmental impact.

The carbonization process requires the greatest amount of the supply of energy in all of GTBE production. In a sensitivity analysis, three different options were considered including energy consumption in the carbonization process (Fig. 7). To reduce the environmental impact at this stage of GTBE production, different energy sources should be used as alternative renewables 


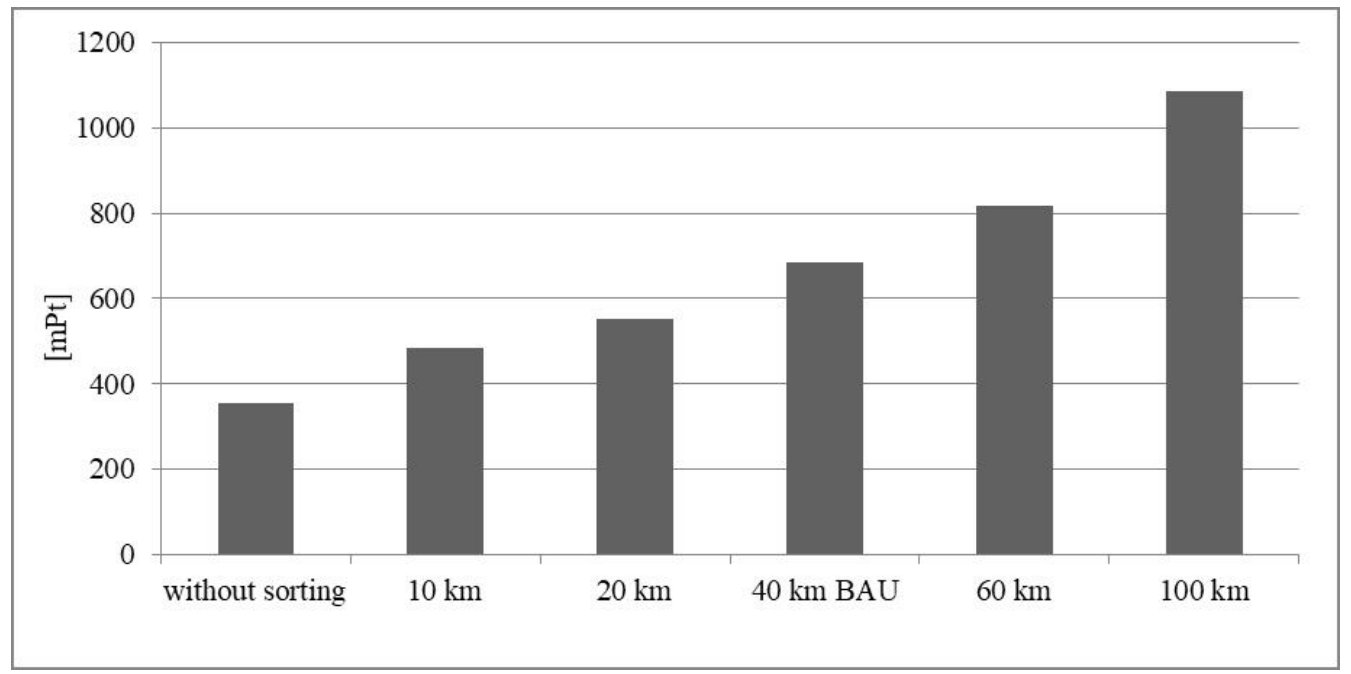

Fig. 6. Environmental impact of the GTBE production for different length of transportation distance of MSW Source: own studies

Rys. 6. Oddziaływanie na środowisko procesu produkcji GTBE w odniesieniu do różnych odległości transportu MSW

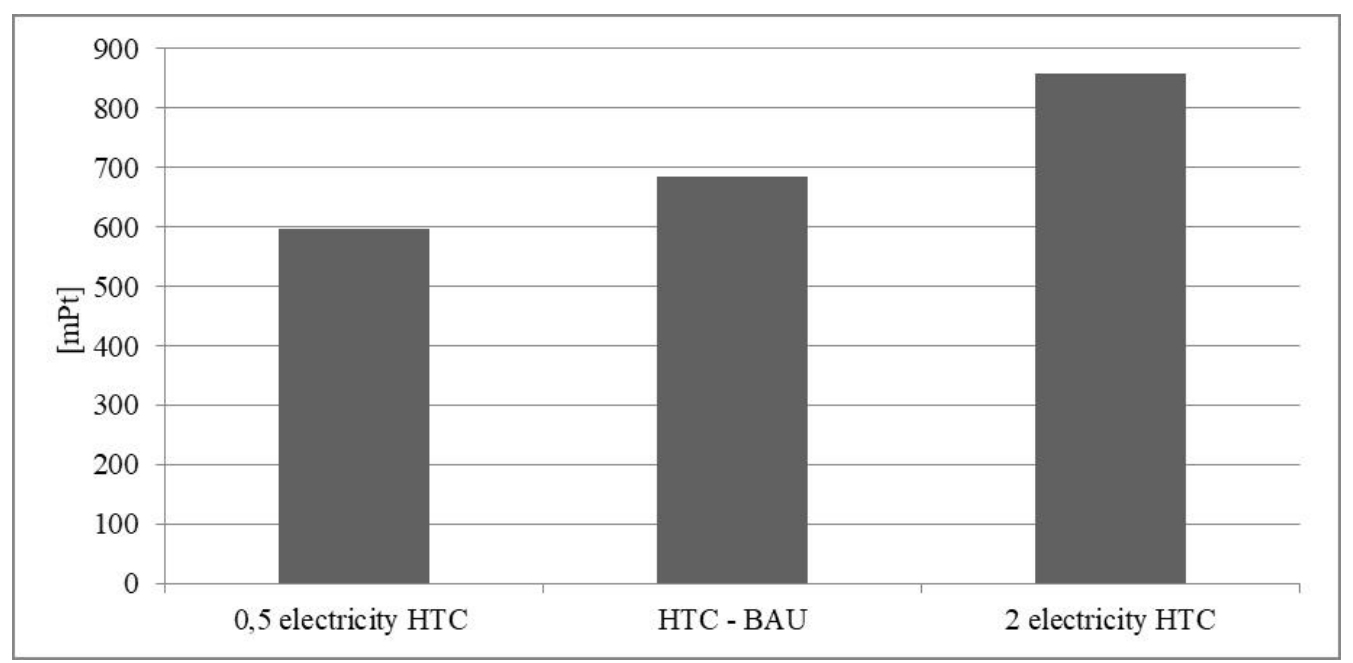

Fig. 7. The environmental impact of GTBE production in relation to the changing amount of electricity consumption in the carbonization process

Source: own studies

Rys. 7. Oddziaływanie na środowisko produkcji GTBE przy zmianie ilości zużytej energii elektrycznej w procesie karbonizacji

to reduce the electricity demand from the grid or to use energy from own source - produced from carbonized biocoal from biomass sludge. 
An energy source can have also a crucial influence on the value of environmental impact. Depending on the type of electricity source: from the grid based on a country mix (Belgium), photovoltaic and natural gas different results for GTBE production were observed (Fig. 8). However, in the Ecoinvent database, there is a lack of data concerning energy production from biocoal pellets or other similar biomass which could be used in BioRen plant and compared as a promising source of energy. Those plants based on biomass are rather still dedicated to heat production than electricity.

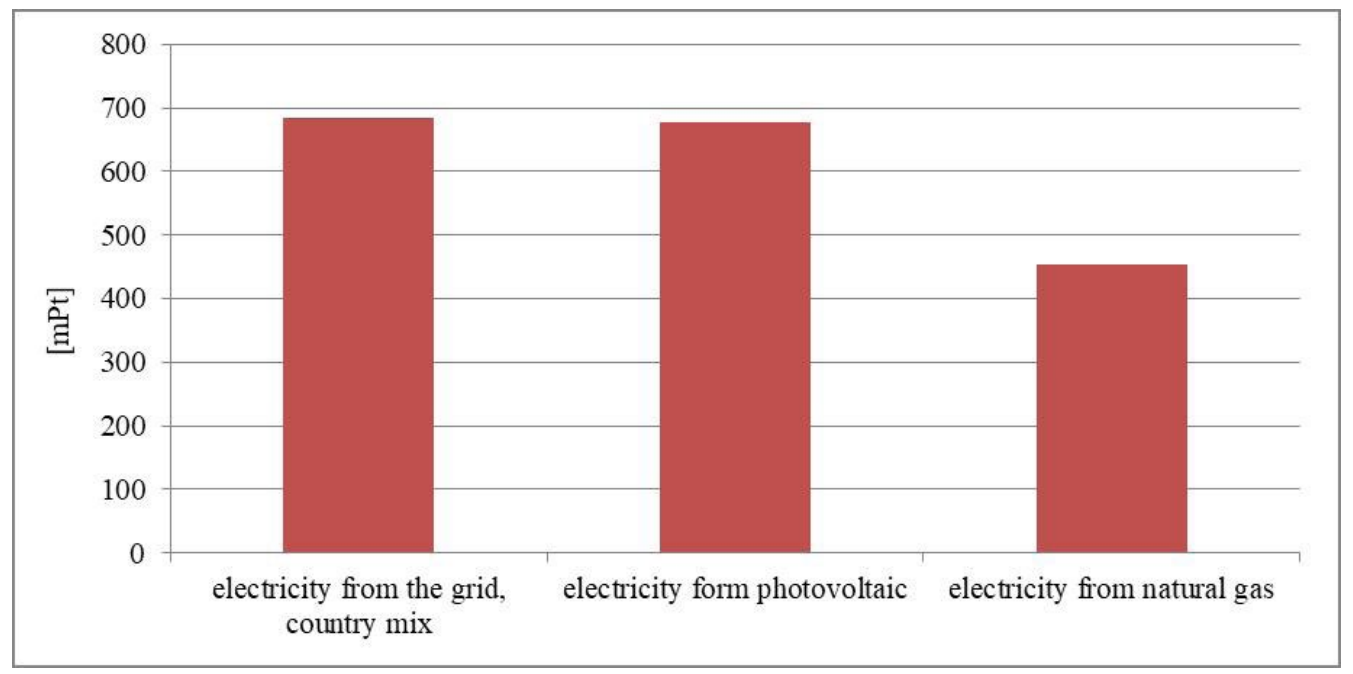

Fig. 8. Environmental impact of GTBE production for different sources of electricity

Source: own studies

Rys. 8. Oddziaływanie na środowisko produkcji GTBE dla różnych źródeł energii elektrycznej

\section{Conclusions}

The results show that the factors most affecting the environment are two processes: sorting and hydrothermal carbonization. This is caused by the waste transport to the plant and electricity consumption. To reduce the environmental impact of the sorting process, the transportation distance of waste should be minimized. The solution is to collect waste in the vicinity of the plant. In the case of hydrothermal carbonization, the most suitable option for reducing the impact would be to close the loop of biocoal production and combustion on-site to generate energy. Moreover, the comparison with conventional fuels also indicates that the environmental impact of GTBE production affects the environment more than diesel fuel or gasoline. This can stem from the fact that the pilot plant will be more energy and materials consuming than verified, reliable, 
conventional technologies. Data was mainly taken from the Ecoinvent database, so final results can vary from those found in the literature. However, the results of this study show the direction of further studies. It points out that the survey should focus on the transport of waste and electricity consumption at the GTBE production stage. In this study, the system boundaries were designed only for GTBE production, so the next step will extend the survey for obtaining GTBE mixed with gasoline and combustion in vehicles engines. The value of cumulative environmental impact changes significantly when the combustion of GTBE will be tested in one system boundaries. The system boundaries and comparing the combustion of conventional fuels may prove a greater contribution to environmental pollution than using the GTBE additive.

\section{References}

Asdrubali et al. 2015 - Asdrubali, F., Cotana, F., Rossi, F., Presciutti, A., Rotili, A. and Guattari, C. 2015. Life Cycle Assessment of New Oxy-Fuels from Biodiesel-Derived Glycerol. Energies 8(3), pp. 1628-1643, DOI: 10.3390/en8031628.

Beatrice et al. 2014 - Beatrice, C., Di Blasio, G., Guido, Ch., Cannilla, C., Bonura, G. and Frusteri, F. 2014. Mixture of glycerol ethers as diesel bio-derivable oxy-fuel: Impact on combustion and emissions of an automotive engine combustion system. Applied Energ, 132, pp. 236-247, DOI: 10.1016/J. APENERGY.2014.07.006.

Borrion et al. 2012 - Borrion, A.L., McManus, M.C. and Hammond, G.P. 2012. Environmental life cycle assessment of lignocellulosic conversion to ethanol. A review. Renewable and Sustainable Energy Reviews 16(7), pp. 4638-4650, DOI: 10.1016/J.RSER.2012.04.016.

Bozkurt et al. 2019 - Bozkurt, Ö.D. Yilmaz, F., BaĞLar, N., Çelebi, S. and Uzun, A. 2019. Compatibility of di- and tri-tert-butyl glycerol ethers with gasoline. Fuel 255, p. 115767, DoI: 10.1016/J. FUEL.2019.115767.

Cherubini et al. 2009 - Cherubini, F., Bargigli, S. and Ulgiati, S. 2009. Life cycle assessment (LCA) of waste management strategies: Landfilling, sorting plant and incineration. Energy 34(12), pp. 2116 -2123. DOI: 10.1016/J.ENERGY.2008.08.023.

DaYlan, B. and Ciliz, N. 2016. Life cycle assessment and environmental life cycle costing analysis of lignocellulosic bioethanol as an alternative transportation fuel. Renewable Energy 89, pp. 578-587. DOI: 10.1016/J.RENENE.2015.11.059.

EEA 2019. European Environmental Agency, 2019. Annual European Union greenhouse gas inventory 1990-2017and inventory report 2019, European Commission, DG Climate Action European Environment Agency.

EP 2019. European Parliament resolution on the 2019 UN Climate Change Conference in Madrid, Spain (COP 25) (2019/2712(RSP)).

EU 2009. Directive 2009/28/EC of the European Parliament and of the Council of 23 April 2009 on the promotion of the use of energy from renewable sources and amending and subsequently repealing Directives 2001/77/EC and 2003/30/EC.

EU 2018. Directive (EU) 2018/2001 of the European Parliament and of the Council of 11 December 2018 on the promotion of the use of energy from renewable sources

European Commission - Joint Research Centre - Institute for Environment and Sustainability, 2011. International Reference Life Cycle Data System (ILCD) Handbook - General guide for Life Cycle Assess- 
ment - Detailed guidance. Luxembourg, Publications Office of the European Union; 2010 [Accessed: 2020-01-15].

Eurostat 2019. Share of energy from renewable sources in transport. [Online] https://ec.europa.eu/eurostat/ web/products-eurostat-news/-/DDN-20190222-1 [Accessed: 2020-02-10].

HuANG, R. and KIm, E.Y. 2015. Catalytic Synthesis of Glycerol tert-Butyl Ethers as Fuel Additives from the Biodiesel By-Product Glycerol, Journal of Chemistry, p. 763854, DOI: 10.1155/2015/763854.

ISO 14040:2006. Environmental management — Life cycle assessment — Principles and framework.

ISO 14044:2006. Environmental management - Life cycle assessment - Requirements and guidelines.

KiJeŃSKi et al. 2007 - KiJeŃSKi, J., JAMróz, M.E. and TęCZA, W. 2007. Research on the use of glycerol in organic synthesis. Part 2: Conversion of glycerol to its tert-butyl ethers (Badania nad wykorzystaniem glicerolu w syntezie organicznej. Cz. 2. Konwersja glicerolu do do jego tert-butylowych eterów), Przemyst Chemiczny 86 (4), pp. 282-285 (in Polish).

Meng et al. 2019 - Meng, F., Ibbett, R., De Vrije, T., Metcalf, P., Tucker, G. and McKechnie, J. 2019. Process simulation and life cycle assessment of converting autoclaved municipal solid waste into butanol and ethanol as transport fuels. Waste Management 89, pp. 177-189, DOI: 10.1016/J.WASMAN.2019.04.003.

Muradin, M. and Cholewa, M. 2019. Production of biofuels from the organic fraction of municipal waste (Produkcja biopaliw z organicznej frakcji odpadów komunalnych). Czasopismo Techniczne KTT No. 180-181, pp. 23-30 (in Polish).

Schmitt et al. 2012 - Schmitt, E. Bura, R., Gustafson, R., Cooper, J. and Vajzovic, A. 2012. Converting lignocellulosic solid waste into ethanol for the State of Washington: An investigation of treatment technologies and environmental impacts. Bioresource Technology 104, pp. 400-409, DOI: 10.1016/J. BIORTECH.2011.10.094.

Singh et al. 2013 - Singh, A., Pant, D., Korres, N., Nizami, A-S., Prasad, S. and Murphy, J. 2013. Key issues in life cycle assessment of ethanol production form lignocellulosic biomass: challenges and perspectives. Bioresource Technology 101, pp. 5003-5012.

Stichnothe, H. and Azapagic, A. 2009. Bioethanol from waste: Life cycle estimation of the greenhouse gas saving potential. Resources, Conservation and Recycling 53(11), pp. 624-630, DOI: 10.1016/J. RESCONREC.2009.04.012.

TAO et al. 2014 - TAO, L., TAN, E., McCormick, R., Zhang, M., Aden, A., He, X. and Zigler, B. 2014. Techno-economic analysis and life-cycle assessment of cellulosic isobutanol and comparison with cellulosic ethanol and n-butanol. Biofuels, Bioproducts and Biorefining 8, DOI: 10.1002/bbb.1431.

ToufiQ Reza et al. 2016 - Toufiq Reza, M., Coronella, Ch.J., Holtman, K.M., Franqui-Villanueva, D. and Poulson, S.R. 2016. Hydrothermal Carbonization of Autoclaved Municipal Solid Waste Pulp and Anaerobically Treated Pulp Digestate. ACS Sustainable Chemistry Engineering 4(7), pp. 3649 -3658, DOI: 10.1021/acssuschemeng.6b00160. 


\title{
Ocena oddziaływania na środowisko technologii przetwarzania organicznych odpadów komunalnych na dodatki do paliw płynnych
}

\begin{abstract}
Streszczenie
W artykule przedstawiono ocenę wpływu na środowisko konwersji frakcji stałej komunalnych odpadów organicznych (MSW) w procesie fermentacji beztlenowej do eteru tert butylowego glicerolu (GTBE). Proces produkcji stanowi część innowacyjnego projektu instalacji do przetwarzania odpadów komunalnych. Projekt BioRen finansowany jest w ramach unijnego programu badań i innowacji „Horyzont 2020”. W celu realizacji projektu i podjęcia konkretnych działań zmierzających do osiągnięcia oczekiwanych rezultatów powołano konsorcjum. Projekt BioRen obejmuje produkcję eteru tert butylowego glicerolu jako dodatku do paliw zarówno do oleju napędowego, jak i benzyny, poprawiającego osiągi silnika i zmniejszającego szkodliwe emisje do środowiska. Jednocześnie do syntezy GTBE planuje się wykorzystywać resztkowe odpady organiczne nienadające się do recyklingu.

Celem niniejszego badania jest ilościowa ocena wpływu produkcji GTBE na środowisko w porównaniu z produkcją innych paliw za pomocą środowiskowej oceny cyklu życia (LCA). W badaniach uwzględniono metodę ILCD 2011 Midpoint+ v.1.10. W ramach badań modeluje się produkcję GTBE obejmującą sortowanie i segregację stałych odpadów komunalnych (MSW), wstępną obróbkę zawartości substancji organicznych, fermentację beztlenową, destylację, katalityczne odwodnienie izobutanolu do izobutenu, eteryfikację oraz hydrotermiczną karbonizację (HTC). Uzyskane wyniki wskazują, iż dwa procesy jednostkowe - sortowanie i hydrotermiczna karbonizacja - mają najwyższe negatywne oddziaływanie na środowisko. Ponadto, analiza LCA wykazała, iż produkcja GTBE posiada znacznie większy wpływ na środowisko niż produkcja paliw konwencjonalnych.
\end{abstract}

SŁowA KLUCzowe: ocena cyklu życia, biopaliwa, organiczne odpady komunalne, dodatki do paliw ciekłych, eter tert butylowy glicerolu 